\title{
Subacute Lung Injury Associated with Heated Tobacco Products
}

\author{
Isıtılmış Tütün Ürünü İlişkili Subakut Akciğer Hasarı
}

\author{
Esen SAYIN GÜLENSOY 1 \\ (1) 0000-0002-0154-7775 \\ Aycan YÜKSEL ${ }^{1}$ \\ (D) 0000-0003-0183-6232 \\ Nalan OGAN ${ }^{1}$ \\ (i) 0000-0001-5232-3803 \\ Haldun UMUDUM ${ }^{2}$ \\ (D) 0000-0002-4550-1971 \\ Evrim Eylem AKPINAR ${ }^{1}$ \\ (D) 0000-0001-9040-9309
}

\begin{abstract}
Heated tobacco products release nicotine without burning tobacco with an electronically controlled heating system. 56-year-old male patient admitted with sudden onset of chest pain and shortness of breath. He had been using a heated tobacco product (I quit ordinary smoking, IQOS) for 2.5 years. Thoracic computed tomography scan revealed pleural-based atelectasis and fibroatelectatic changes in the lower lobe of the right lung, pleural fluid in the right upper lobe, fibroatelectatic changes and pleural thickening in the left lung. Biopsy taken with videoassisted thoracic surgery (VATS) showed lymphoid aggregation in nodular form and widespread anthracosis around the lung, fibrillar material that double-refracting the light in the alveoli, hyaline membrane-like material in the alveoli, type 2 pneumocyte hyperplasia, an interstitial organization, and a subacute lung injury picture with exogenous lipoid material. These findings were evaluated in accordance with toxic substance-induced chemical pneumonia. It was thought that it might be related to 2.5 years of using heated tobacco product. Keywords: Tobacco products; tobacco smoking; lung injury.
\end{abstract}

ÖZ

Isıtılmış tütün ürünleri elektronik olarak kontrol edilen bir 1sıtma sistemi ile tütün yakmadan nikotin açığa çıkaran ürünlerdir. 56 yaşında erkek hasta ani başlangıçlı nefes darlığı ve göğüs ağrısı şikayetleriyle başvurdu. 2,5 yıldır 1sıtılmış tütün ürünü (I quit ordinary smoking, IQOS) kullanıyordu. Toraks bilgisayarlı tomografi tetkikinde sağ akciğer alt lobda plevra tabanlı atelektazi ve fibroatelektatik değişiklikler, sağ üst lobda plevral sıvı, sol akciğerde fibroatelektatik değişiklikler ve plevral kalınlaşma izlendi. Video yardımlı toraks cerrahisi (video-assisted thoracic surgery, VATS) ile alınan biyopsi de akciğerde nodüler halinde lenfoid agregasyon ve çevresinde yaygın antrakoz, alveol içinde 1 şı̆̆ı çift kıran fibriler materyal, alveol içinde hyalin membran benzeri materyal, tip 2 pnömosit hiperplazisi, interstisyel bir organizasyon ve ekzojen lipoid materyalin izlenmekte olduğu bir subakut akciğer hasarı tablosu izlendi. Bu bulgular toksik madde kaynaklı kimyasal pnömoni ile uyumlu olarak değerlendirildi. Bunun hastanın 2,5 yıllık 1sıtılmış tütün kullanımına bağlı olduğu düşünüldü. Anahtar kelimeler: Tütün; tütün içimi; akciğer hasarı.

\section{INTRODUCTION}

In conventional cigarettes, when tobacco is heated above $600{ }^{\circ} \mathrm{C}$, burning occurs and the result is smoke containing harmful chemical (1). Heated tobacco products, heat tobacco up to $350{ }^{\circ} \mathrm{C}$, releasing volatile components (2). Heated tobacco products release nicotine-containing emissions without burning tobacco using an electronically controlled heating element. Tobacco companies marketing the heated 
tobacco products using the messages claiming to be safer than cigarettes (3). The I quit ordinary smoking (IQOS) device, a heated tobacco product, was developed by Philip Morris International (PMI) and launched in international markets in mid-2014. It was available in 51 countries by May 2020 (4).

The variety and prevalence of nicotine-containing devices such as heated tobacco products are increasing day by day. However, there is less information about their effects on the lungs.

\section{CASE REPORT}

A 56-year-old male admitted with sudden onset of chest pain and shortness of breath. The patient had a history of chronic obstructive lung disease, coronary artery disease, and previous pulmonary embolism. He had smoked approximately 25 pack years and quit. He had been using a heated tobacco product, IQOS, for 2.5 years. There was no history of any other substance use. The initial bloodwork during the admission of the patient: WBC: $7.99 \times 10^{3} / \mathrm{uL}, \mathrm{N}: 70.6 \%, \mathrm{~L}: 17.2 \%$. The procalcitonin level was $0.06 \mathrm{ng} / \mathrm{ml}$, ESR was $54 \mathrm{~mm} / \mathrm{h}, \mathrm{CRP}$ was $42.2 \mu \mathrm{g} / \mathrm{L}$. The other all laboratory tests were negative. Pleural-based parenchymal infiltration and accompanying fibroatelectatic densities in the posterior basilar segment of the right lung were observed on the computed tomografy (CT) scan. Because of clinical deterioration on antibiotics, progression on chest X-ray, and no growth on cultures, repeat thoracic CT examination was performed. Pleuralbased atelectasis and fibroatelectatic changes in the lower lobe of the right lung, pleural fluid in the right upper lobe, fibroatelectatic changes in the left lung and pleural thickening were observed (Figure 1). Partial decortication and wedge resection was performed with video-assisted thoracic surgery (VATS). Visceral aspect of lung parenchyma as a result of the pathological examination of the material taken. Subpleural fibrotic thickening is seen (Figure 2.A), subpleural fibrosis and anthracotic pigments in lung parenchyma (Figure 2.B), nodular lymphoid aggregates in perialveolar areas (Figure 2.C), prominent interstitial edema is seen (Figure 2.D), hyaline membrane like material is present in alveoli (Figure 2.E). A fibrillary protein like foreign material is present in many alveoli (shown in circles) in HE stained sections (Figure 3.A). These materials are also birefringent in polarized microscopy (as indicated with arrows, Figure 3.B). Presence of such birefringent material in alveoli is not physiological and most likely represents a deposition of inhaled dust (Figure 3). These findings were evaluated in accordance with chemical pneumonia caused by one or more toxic substances. The general condition was found to be compatible with subacute lung injury.

\section{DISCUSSION}

In the United States in 2019, acute respiratory diseases that mimic a viral disease that cannot be explained by any other disease were detected in patients with a history of e-cigarette use in the last ninety days. This disease was named with e-cigarette or vaping product use-associated lung injury (EVALI) when evaluated by imaging methods and histopathologically.

EVALI patients typically had a nonspecific clinical presentation characterized by a combination of respiratory, gastrointestinal, and constitutional symptoms. CT findings in EVALI were most commonly pneumonia and diffuse alveolar damage. Less common forms of lung injury have been reported, including acute eosinophilic pneumonia and widespread alveolar bleeding. Histological findings were not specific. There were macrophages in alveoli containing lipid and granular brown-black refractile foreign material. There was a small amount of neutrophils and eosinophils. There was prominent type 2 pneumocyte

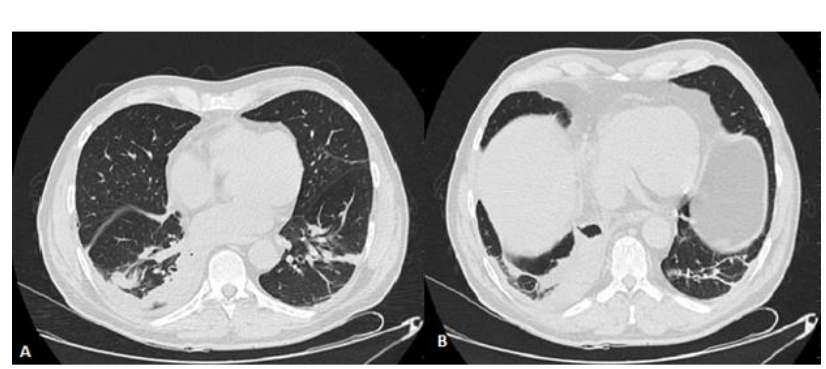

Figure 1. Pleural-based atelectasis and fibroatelectatic changes in the lower lobe of the right lung, fibroatelectatic changes in the left lung and pleural thickening

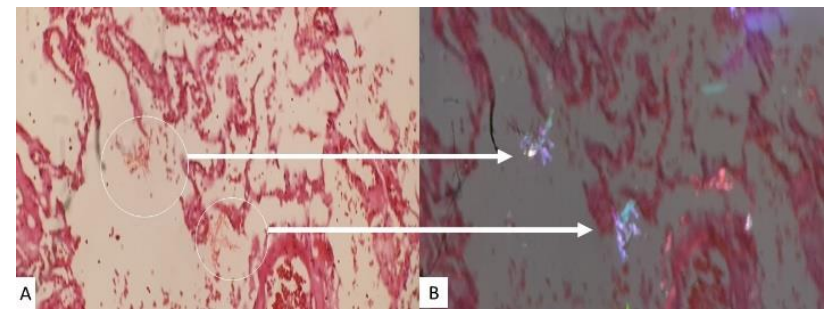

Figure 3. A) A fibrillary protein like foreign material in many alveoli (shown in circles) in HE stained sections, B) These materials are also birefringent in polarized microscopy (as indicated with arrows)

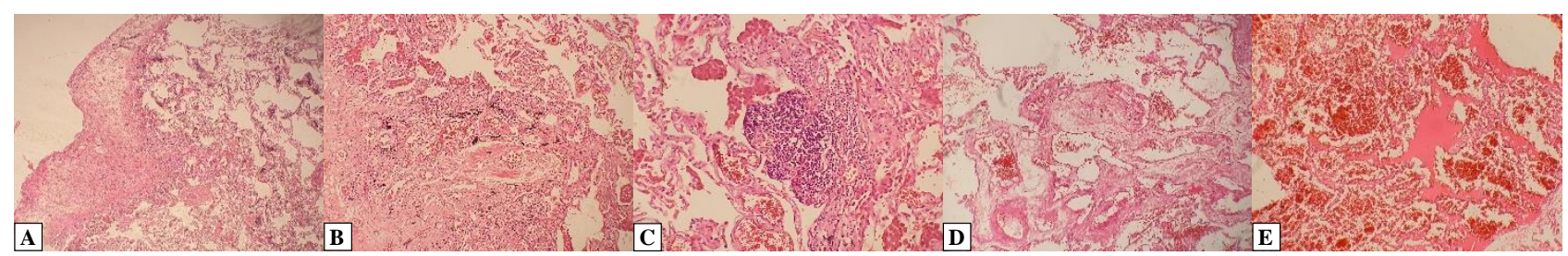

Figure 2. Visceral aspect of lung parenchyma, A) Subpleural fibrotic thickening (H\&E, x20), B) Subpleural fibrosis and antrachotic pigments in lung parenchyma (H\&E, x20), C) Nodular lymphoid aggregates in perialevolar areas (H\&E, x20), D) Prominent interstitial edema (H\&E, x10), E) Hyalin membrane like material in alveoli (H\&E, x20) 
hyperplasia with prominent nucleolus and multinucleation. There were also scattered mitotic figures. Findings showed patterns of acute lung injury, including acute fibrinous pneumonitis, diffuse alveolar damage, or pneumonia often seen with bronchiolitis and bronchiolitis. Foamy macrophages and pneumocyte vacuolization were seen in all cases. Pigmented macrophages were sometimes present but not a dominant feature. It has been reported that the findings suggest an airway-centered chemical pneumonitis from one or more inhaled toxic substances $(5,6)$.

In our case, a subacute lung injury was observed in which lymphoid aggregation in nodular form with surrounding extensive anthracosis, fibrillar material that doublerefracting the light in the alveoli, hyaline membrane-like material in the alveoli, fibrotic nodules, type 2 pneumocyte hyperplasia, an interstitial organization and exogenous lipoid material were seen.

Although e-cigarette use-associated lung injury have been defined, there is no definition associated with the use of heated tobacco products in the literature. Although tobacco producers introduce heated tobacco products to the market as a safer product compared to cigarettes, studies have shown that the emissions of heated tobacco products also have a cytotoxic effect on the human bronchial epithelium (7). Heated tobacco products also emit significant levels of tobacco-specific nitrosamines similar to conventional cigarettes. Although heated tobacco products emit lower amounts of tobacco-specific nitrosamines than flammable cigarettes, the amounts are significantly higher than e-cigarettes (8-10).

In conclusion, the presence of biopsy findings due to toxic or irritant substance inhalation in our patient might be related to the heated tobacco product he was using. We would like to emphasize that chemical pneumonia should not be forgotten in cases of pneumonia that do not respond to conventional treatments in individuals smoking such products. Although tobacco companies present a less harmful alternative to traditional cigarettes, it is clear that further studies are needed on products of the heated type.

Informed Consent: Written informed consent was obtained from the patient for publication and accompanying images.

Conflict of Interest: None declared by the authors.

Financial Disclosure: None declared by the authors.
Acknowledgements: None declared by the authors.

Author Contributions: Idea/Concept: ESG; Design: ESG, EEA; Data Collection/Processing: AY, HU; Analysis/Interpretation: ESG, HU; Literature Review: NO, EEA; Drafting/Writing: ESG, EEA; Critical Review: AY, NO.

\section{REFERENCES}

1. Caraballo RS, Pederson LL, Gupta N. New tobacco products: do smokers like them? Tob Control 2006;15(1):39-44.

2. Goniewicz ML, Knysak J, Gawron M, Kosmider L, Sobczak A, Kurek J, et al. Levels of selected carcinogens and toxicants in vapour from electronic cigarettes. Tob Control 2014;23(2):133-9.

3. Kim M. Philip Morris International introduces new heat-not-burn product, IQOS, in South Korea. Tob Control. 2018;27(e1):e76-8.

4. Leigh NJ, Tran PL, O’Connor RJ, Goniewicz ML. Cytotoxic effects of heated tobacco products (HTP) on human bronchial epithelial cells. Tob Control. 2018;27(Suppl 1):s26-9.

5. Kligerman S, Raptis C, Larsen B, Henry TS, Caporale A, Tazelaar H, et al. Radiologic, pathologic, clinical, and physiologic findings of electronic cigarette or vaping product use-associated lung injury (EVALI): Evolving knowledge and remaining questions. Radiology. 2020;294(3):491-505.

6. Butt YM, Smith ML, Tazelaar HD, Vaszar LT, Swanson KL, Cecchini MJ, et al. Pathology of vapingassociated lung injury. $\mathrm{N}$ Engl J Med. 2019;381(18):1780-1.

7. Leigh NJ, Palumbo MN, Marino AM, O'Connor RJ, Goniewicz ML. Tobacco-specific nitrosamines (TSNA) in heated tobacco product IQOS. Tob Control. 2018;27(Suppl 1):s37-8.

8. Marsden L, Michalicek ZD, Christensen ED. More on the pathology of vaping-associated lung injury. N Engl J Med. 2020;382(4):387-8.

9. Davidson KR, Fox DL. More on the pathology of vaping-associated lung injury. $N$ Engl $J$ Med. 2020;382(4):388.

10. Larsen BT, Butt YM, Smith ML. More on the pathology of vaping-associated lung injury. Reply. $\mathrm{N}$ Engl J Med. 2020;382(4):388-90. 